\title{
Do factors influencing recruitment ultimately determine the distribution and abundance of encrusting algae on seasonal tropical shores?
}

\author{
S. Kaehler*, Gray A. Williams** \\ The Swire Institute of Marine Science and Department of Ecology and Biodiversity, The University of Hong Kong, \\ Pokfulam Road, Hong Kong
}

\begin{abstract}
Similar to many low-latitude shores, encrusting algae are the dominant space-occupying organisms on moderately exposed rocky shores in Hong Kong. A multifactorial experiment assessed the roles of herbivory, season, tidal height and substratum inclination on the initial recruitment of encrusting algae to artificial surfaces. Herbivores reduced recruit densities at certain times of the year and tidal heights, but did not prevent settlement. [n contrast, the relative timing of recruitment and the prevailing environmental conditions greatly affected recruit success. No species recruited at any time to the high shore, and species recruited as high as the mid shore only during cooler months. Species that recruited during the cooler months (e.g. Hapalospongidion gelatinosum and coralline crusts) could colonise the mid shore, while Ralfsia expansa, which recruited primarily during the hot season, was restricted to the low shore and subtidal. Recruitment also varied with substratum inclination; coolseason recruits were found in greater densities on horizontal surfaces, whereas hot-season recruits exhibıted no difference between horizontal and vertıcal plates. Seasonal availability of free space may influence the life-history strategies of encrusting algae. $R$. expansa recruited during the hot season to the low shore, when free space was available following the annual die-back of algae. In contrast, coolseason recruits (e.g. H. gelatinosum) have less free space to colonise and as a result become established in greater densities higher on the shore, resulting in increased physical stress and mortality during the following hot season. The timing of recruitment relative to spatial and temporal variation in the physical environment, therefore, greatly affects the potential distribution of mature encrusting algal populations on Hong Kong shores.
\end{abstract}

KEY WORDS: Encrusting algae Recruitment Herbivores. Physical stress Hong Kong - Seasonal variation S Settlement Tropical shores

\section{INTRODUCTION}

The distribution and abundance of marine macroalgae vary both spatially and temporally under the influence of a variety of physical and biological factors (reviewed by Dayton 1985, Norton 1985, Underwood 1985). Compared to numerous studies of the effects of

\footnotetext{
Present addresses:

- Department of Zoology and Entomology, Rhodes University, PO Box 94, Grahamstown 6140, South Africa

E-mail:zosk@giraffe.ru.ac.za

- Department of Ecology and Biodiversity, The University of

Hong Kong, Pokfulam Road, Hong Kong
}

herbivory, physical disturbance and stress on the abundance of adult macroalgae relatively little is known about the importance of early settlement and recruitment processes in establishing algal distribution patterns, especially of encrusting algae on tropical shores (Underwood \& Denley 1984, Underwood 1985, 1991, Menge \& Farrell 1989, Underwood \& Fairweather 1989, Brosnan 1992). This stage, however, is crucial as the establishment of algal populations is often directly dependent on the ability of algae to initially colonise the substratum. Furthermore, in highly disturbed habitats where adult mortality is greater than lateral re-growth, the persistence of a species may depend on successful recruitment of propagules onto 
newly liberated surfaces (Reed et al. 1988, Fletcher \& Callow 1992, Benedetti-Cecchi \& Cinelli 1993, Kendrick \& Walker 1994)

Unlike the planktonic larvae of many marine invertebrates, algal propagules exhibit little to no motility (Fletcher \& Callow 1992) and active site selection is thought to be of little importance in determining colonisation patterns (Chamberlain 1976, Norton \& Fetter 1981). Instead, the distribution of new recruits is influenced by a wide variety of physical and biological factors that act on propagule availability and dispersal (e.g. Deysher \& Norton 1982, Hoffmann \& Ugarte 1985), the arrival and establishment of settlers on the shore (e.g. Norton \& Fetter 1981, Hoffmann 1987. Benedetti-Cecchi \& Cinelli 1992) and early post-settlement mortality (e.g. Underwood 1980, Jernakoff 1983. Santelices \& Ojeda 1984, Ang 1991, Geller 1991, Kendrick 1994). Recruitment (the addition of individuals to a unit of population; Doherty \& Williams 1988) is thus determined by all processes that affect settlement (the point when individuals first take permanent residence on the substratum) and the early survival of the settlers up to the time of the first census (Keough \& Downes 1982, Connell 1985).

In Hong Kong, shores of intermediate exposure are frequently dominated (in terms of total cover) by encrusting algal species, many of which exhibit distinct spatial and temporal distribution patterns (Williams 1993a, b, Kaehler 1994, Kaehler \& Williams 1996). The distribution of these populations may be related to physical (e.g. heat and desiccation stress) and biological factors (e.g. herbivory and competition) that act on adult mortality (Kaehler \& Williams 1996), but little is known about the importance of recruitment. In Hong Kong, recruitment is likely to be of great importance in determining species distributions, as large areas of mid and low shore substratum are annually made available due to die-backs of space-occupying species with the advent of the hot season (Kaehler \& Williams 1996)

This study investigates the importance of early $(\leq 1 \mathrm{mo}$ ) recruitment processes in determining the distribution patterns of encrusting algae with reference to season, tidal height and inclination. The effect of herbivory on recruitment was also investigated by experimentally excluding molluscan and echinoid grazers, therefore allowing an assessment of the interaction between physical and biological factors in determining the potential distribution of encrusting algae.

\section{MATERIALS AND METHODS}

Study site. A $15 \mathrm{~m}$, west facing, stretch of shoreline located inside Lobster Bay on the Cape d'Aguilar peninsula, Hong Kong (220 $\left.13^{\prime} \mathrm{N}, 114^{\circ} 12^{\prime} \mathrm{E}\right)$ was selected as being typical of local rocky shores of intermediate exposure. Encrusting algae were the most abundant macroalgae present and exhibited a 4-banded zonation pattern consisting of a Kyrtuthrix zone on the high shore, a Bare zone on the mid shore, a Mixed zone on the low shore and a Coralline-crust zone in the subtidal. Sessile invertebrates and erect macroalgae were rare (overall $<5 \%$ cover). Herbivores occurred in high densities and consisted of echinoids in the subtidal and molluscs at all tidal heights. During the cool season, the high shore was dominated by littorinids (densities of $>200 \mathrm{~m}^{-2}$ ), the mid and low shore by limpets (mainly Cellana spp., up to $80 \mathrm{~m}^{-2}$ ), chitons (Acanthopleura japonica, up to $30 \mathrm{~m}^{-2}$ ), and low densities of Monodonta labio and Nerita albicilla. The subtidal supported rhipidoglossan snails (mainly Lunella sp., Chlorostoma sp., M. labio and $N$. albicilla, up to $200 \mathrm{~m}^{-2}$ ) and urchins (Anthocidaris crassispina, several $\mathrm{m}^{-2}$ ) and low numbers of herbivorous fish (Entomacrodus stellifer) and hermit crabs. Low densities of the herbivorous crab Grapsus albolinetaus foraged over the intertidal. During the hot season many molluscs are killed or migrate down shore, resulting in the densities of many species being reduced by $\sim 50 \%$ (for more details see Williams 1993b, Kaehler \& Williams 1996). Some of these herbivores (limpets, chitons and urchins) preferentially consume encrusting algae, but all of the herbivores are capable of ingesting newly settled spores and juvenile algae (Kaehler 1996).

Experimental design. To remove the confounding effects of substratum heterogeneity and therefore facilitate comparison of recruitment rates from different seasons, tidal heights and inclinations, uniform settlement surfaces (roughened PVC plates, $160 \times 90 \times$ $3 \mathrm{~mm}$ ) were used. This material allows recruitment of coralline as well as non-calcified encrusting algae (Adey \& Vassar 1975) and, except in situations of heavy fish grazing, supports similar assemblages of algae as compared to natural surfaces (Hixon \& Brostoff 1985). Plates were fixed onto the shore by attaching them to plastic bolts cemented (Wet Surface Epoxy Putty, Devcon) into holes in the rock surface. Plates remained on the shore for 1 mo, after which they were removed and scored in the laboratory. At 1 mo most recruits were large enough ( 1 to $5 \mathrm{~mm}$ ) for identification but still small enough not to interfere with each other.

The experiment utilized an orthogonal design to investigate the factors herbivory, season, tidal height and inclination on recruit density (Fig. 1). Three treatments were used to investigate the influence of herbivores. Herbivores were excluded from the plates, using $3 \mathrm{~cm}$ high, $18 \times 11 \mathrm{~cm}$ stainless steel mesh 'exclusion fences' ( $4 \times 4 \mathrm{~mm}$ mesh size). Weekly observations were made at high tide, either by snorkelling or 

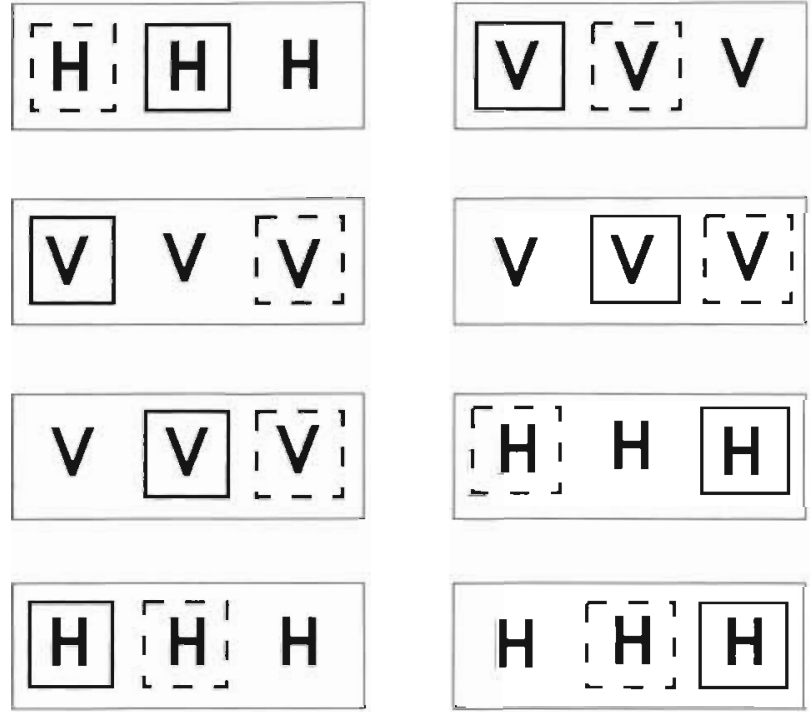

Fig. 1. Schematic representation of plate arrangement at one tidal height. Blocks contain all 3 randomly allocated herbivore treatments and are interspersed on horizontal $\left(\mathrm{H}=0\right.$ to $\left.30^{\circ}\right)$ and on vertical surfaces $\left(V=60\right.$ to $\left.90^{\circ}\right)$. The design was repeated at 4 tidal heights and during 5 sampling periods. Full box: exclusion fence; dashed box: fence control (half fence); no box: open plates (unmanipulated grazer density)

SCUBA, of experimental areas. At only one time was a molluscan herbivore (Chlorostoma sp.) seen in the exclusion treatment. Echinoids were never present, but fish and hermit crabs were occasionally seen to graze in subtidal exclusion treatments. The fences were, therefore, successful at excluding molluscan and echinoid herbivores but allowed access, having no roof, to highly mobile hermit crabs and fish. 'Open plates' allowed full access to all herbivores and 'halffence plates' (fences along 2 opposite sides of the plates) permitted herbivore entry while providing a control for possible fence effects. The effects of inclination on recruitment were tested by fixing plates onto both horizontal $\left(0\right.$ to $30^{\circ}$ ) and vertical rock surfaces (60 to $90^{\circ}$, west facing where possible). Variation in recruitment patterns with tidal height were investigated by attaching plates at 4 different tidal heights corresponding with the 4 main algal zonation bands (Kyrtuthrix zone $\approx 1.75 \mathrm{~m}$, Bare zone $\approx 1.25 \mathrm{~m}$, Mixed zone $\approx 0.75 \mathrm{~m}$, Coralline-crust zone $\approx-0.25 \mathrm{~m}$ above chart datum). For simplicity, the 4 tidal heights are referred to as high, mid, low shore and the subtidal. Finally, temporal patterns in recruitment were investigated by repeating the entire design, with new plates, at 3 mo intervals from April 1992 to April 1993. July 1992 and January 1993 were representative of the extremes of the hot and cool seasons respectively, while April and October were monsoonal transition periods (see Kaehler \& Williams 1996).
The arrangement of treatments of the 3 factors herbivory, inclination and tidal height was based on a randomised block design (see Hurlbert 1984). The smallest block consisted of the 3 randomly allocated herbivore treatments which were interspersed on horizontal and vertical surfaces (Fig. 1), at 4 tidal heights. There were 4 replicates of each treatment and the experiment was repeated over 5 time periods $\left(\sum \mathrm{n}=\right.$ 480 plates).

Determination of recruitment density. The density of recruits on the plates was determined in the laboratory. Two randomly chosen areas $\left(16 \mathrm{~cm}^{2}\right)$ were studied at low power under a dissection microscope (Wild), and where possible, individuals were identified and scored. Areas were selected at random from within an area of $84 \mathrm{~cm}^{2}$, allowing at least $1 \mathrm{~cm}$ distance from the plate perimeter to eliminate possible edge effects (Foster 1975). The mean number of recruits per unit area $\left(\mathrm{cm}^{-2}\right)$ was calculated from the 2 subsamples for each plate.

The effects of herbivory, inclination, tidal height and time of year on density of algal recruitment were analysed using multifactorial ANOVAs. Data were square-root-transformed to normalise distributions and/or homogenise variances when these assumptions were initially violated (Zar 1984). Bonferroni corrections were applied to maintain the probability of an overall Type I experimental error at $5 \%$. SNK multiple comparison procedures were used to further investigate significant differences (Zar. 1984).

\section{RESULTS}

Due to the small size of encrusting algal recruits (usually $<5 \mathrm{~mm}$ ), only individuals of Hapalospongidion gelatinosum, Ralfsia expansa, the coralline crusts, Hildenbrandia sp., Dermocarpa sp. and Peyssonnelia spp. could be distinguished and identified on the plates (Table 1). Of these, only the first 3 were sufficiently abundant to warrant statistical analysis. Several of the species (i.e. Hildenbrandia sp., Dermocarpa sp., Ulva sp. and Colpomenia sinuosa) were extremely rare (overall < 30 individuals during all 5 study periods), while other organisms (erect algae and sessile invertebrates) were slightly more abundant but were patchily distributed (Table 1).

\section{Effects of herbivory on recruitment}

Herbivory generally reduced the recruitment of all 3 abundant encrusting algal groups (Tables 2-4. Figs. 2-4). There was, however, no significant difference between half-fenced plates (fence controls) and 
Table 1. Overall mean recruitment denslties $\mathrm{cm}^{-2}$ (SE in parentheses, $\mathrm{n}=96$ ) of all organisms identified on the experimental plates with time. nr: no recruitment

\begin{tabular}{|c|c|c|c|c|c|}
\hline & Apr 1992 & Jul 1992 & Oct 1992 & Jan 1993 & Apr 1993 \\
\hline \multicolumn{6}{|l|}{ Encrusting algae } \\
\hline Hapalospongidion gelatinosum & $4.57(0.92)$ & $0.67(0.30)$ & $0.07(0.02)$ & $21.0(2.95)$ & $8.75(1.58)$ \\
\hline Ralfsia expansa & nr & $8.67(1.96)$ & $1.76(0.64)$ & nr & $\mathrm{nr}$ \\
\hline Coralline crusts & $1.31(0.32)$ & $2.12(0.73)$ & $2.93(0.64)$ & $9.78(1.46)$ & $3.16(1.09)$ \\
\hline Dermocarpa sp. & $<0.01$ & nr & $\mathrm{nr}$ & nr & nr \\
\hline Hildenbrandia sp. & $0.02(0.01)$ & $n r$ & $n r$ & $\mathrm{nr}$ & $\mathrm{nr}$ \\
\hline Peyssonnelia spp. & nr & $1.89(0.87)$ & $<0.01$ & $0.04(0.02)$ & $0.01(0.01)$ \\
\hline \multicolumn{6}{|l|}{ Erect algae } \\
\hline Colpomenia sinuosa & $\mathrm{nr}$ & $\mathrm{nr}$ & $\mathrm{nr}$ & $<0.01$ & $<0.01$ \\
\hline Gelidium spp. & $\mathrm{nr}$ & $\mathrm{nr}$ & nr & $0.02(0.01)$ & $<0.01$ \\
\hline Porphyra sp. & $\mathrm{nr}$ & $\mathrm{nr}$ & $\mathrm{nr}$ & $0.64(0.26)$ & $\mathrm{nr}$ \\
\hline Ulva sp. & $\mathrm{nr}$ & $\mathrm{nr}$ & $\mathrm{nr}$ & $<0.01$ & $<0.01$ \\
\hline Brown spores & $\mathrm{nr}$ & $\mathrm{nr}$ & nr & $0.22(0.15)$ & $0.10(0.09)$ \\
\hline Green spores & $\mathrm{nr}$ & $\mathrm{n}, \mathrm{r}$ & $2.11(0.89)$ & $0.11(0.03)$ & $0.29(0.19)$ \\
\hline \multicolumn{6}{|l|}{ Sessile invertebrates } \\
\hline Barnacles & $0.02(0.01)$ & $0.04(0.02)$ & $<0.01$ & $0.01(0.01)$ & $0.76(0.27)$ \\
\hline Spirorbids & $0.38(0.14)$ & $1.60(0.50)$ & $0.27(0.09)$ & $0.04(0.01)$ & $0.34(0.11)$ \\
\hline
\end{tabular}

open plates, suggesting that the fences successfully excluded molluscan and echinoid herbivores, but did not otherwise affect recruitment.

Interaction terms revealed that for most groups the effect of herbivory was highly dependent on the time of year and/or on tidal height (Tables $2 \& 3$ ). For both Hapalospongidion gelatinosum and Ralfsia expansa, the effect of herbivory was only significant during times of increased recruitment (January and July respectively), and in the case of $R$. expansa herbivory effectively reduced recruitment only on the low shore and not in the subtidal (Tables $2 \& 3$, Figs. 2 \& 3).

\section{Variation in recruitment with physical factors}

All 3 abundant encrusting algal groups exhibited variation in recruitment density with time (Tables $2-4$, Figs. 2-4). While the coralline crusts recruited throughout the year with a peak in January (Table 4 , Fig. 4), the 2 brown crusts had periods of greatly reduced or no recruitment. Hapalospongidion gelatinosum recruited mainly during the cooler months, especially January, with a significant reduction during the hot season (Table 2) while Ralfsia expansa recruited primarily during the hot season, with a peak in July (Tables $1 \& 3$ ). No recruits of $R$. expansa were observed during January or either April (Fig 3)

For most of the time, recruitment was restricted to the low shore and subtidal. No species recruited onto the high shore at any time and only during times of reduced physical stress (cool air temperatures and higher low tides, January and April) did recruitment occur onto the mid shore (Figs. 2-4). Ralfsia expansa, which recruited only during the hottest months, was always restricted to the low shore and subtidal (Fig. 3). In contrast, species that recruited during the cooler months (Hapalospongidion gelatinosum and the coralline crusts), colonised higher on the shore (Figs. $2 \& 4$ ).

Recruitment also varied with substratum inclination (Tables 2 \& 4). For both Hapalospongidion gelatinosum and the coralline crusts, recruitment was significantly greater on horizontal surfaces than on vertical surfaces (Figs. $2 \& 4$ ). In both species, however, the effect of inclination interacted with time and, for the coralline crusts, with tidal height (Fig. 4). Recruitment of both $H$. gelatinosum and the coralline crusts was more dense on horizontal plates only during the cooler months and exhibited no difference during the hot season (Tables 2 \& 4). Coralline-crust recruits were significantly more abundant on horizontal surfaces in the subtidal, for most of the year (Table 4, Fig. 4). Ralfsia expansa, which recruited only during the hot season, did not exhibil any differences with surface orientation, either alone or in combination with time and/or tidal height (Table 3, Fig. 3).

\section{Recruitment patterns of rare species}

Although no statistical tests were performed on the rare and patchily distributed species (Table 5) several broad patterns were apparent. In all species (algae as well as invertebrates), recruitment varied with time (Table 1). While the majority of species recruited during the cooler months (January, April 1992 and 1993), 
Table 2. Hapalospongidion gelatinosum. Four-way ANOVA of recruit densities (mean number of individuals $\mathrm{cm}^{-2}$ ) by time, tidal height, herbivory and inclination. Sign.. significance after Bonferroni correction; ${ }^{p} p<0.05$ (0.0166); ${ }^{\circ p}<$ $0.01(0.0033)$; ns: not significant. Significant differences were further analysed using SNK multiple comparison tests. Treatment abbreviations are: $M$ : mid shore; $L$ : low shore; $S$ : subtidal; $O$ : open plates; $C$ : fence control; $E$ : exclusion plates (fully fenced); $V$ - vertical; $H$ : horizontal

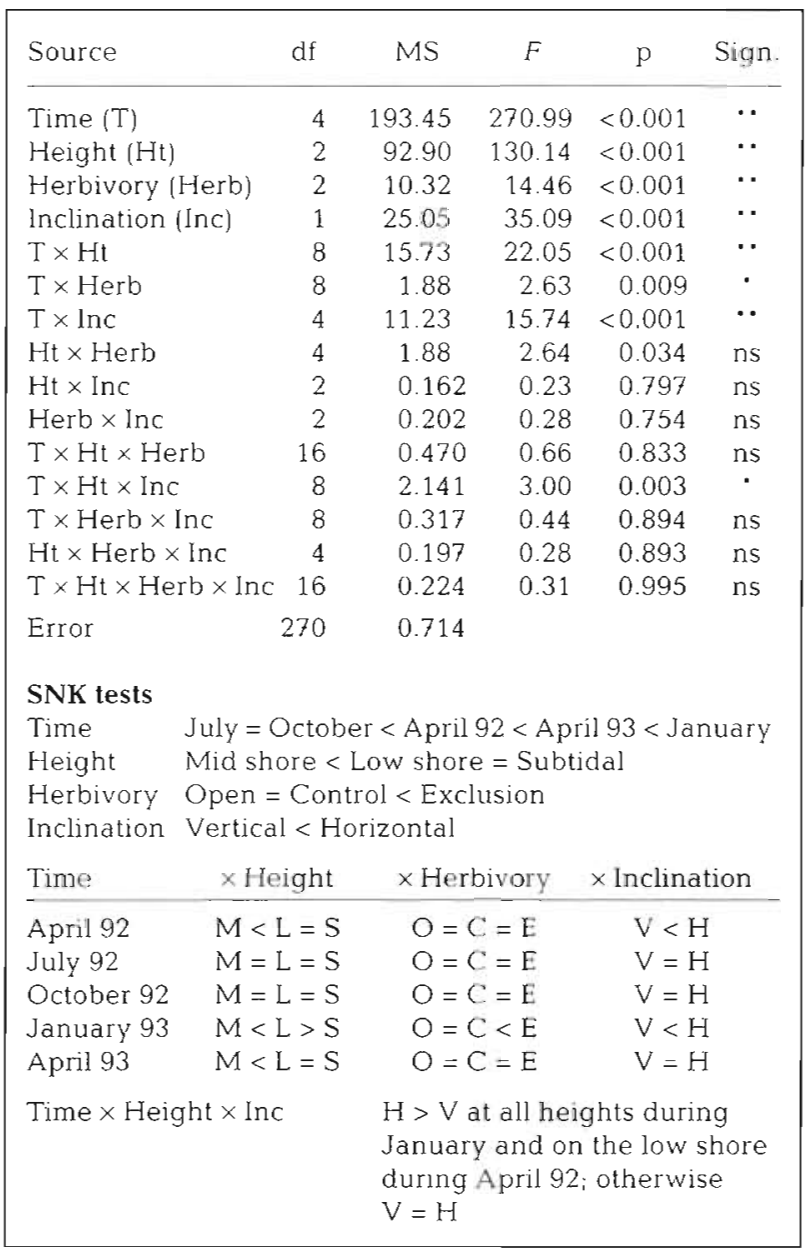

some species (e.g. Peyssonnelia spp., green spores and spirorbids) recruited in greatest abundance during July and/or October.

The effect of molluscan and echinoid herbivory on recruitment was most pronounced for the erect macroalgae (Table 5). Herbivory did not seem to effect recruitment success of Peyssonnelia spp. or the sessile invertebrates. Recruitment was generally greatest on the low shore and in the subtidal and no species recruited at any time onto the high shore. Peyssonnelia spp. was, however, most abundant on, and Porphyra only colonised, the mid shore (Table 5). Except for Porphyra sp. and spirorbids most algal species either recruited in greater numbers on horizontal surfaces than vertical surfaces or were equally distributed (Table 5).
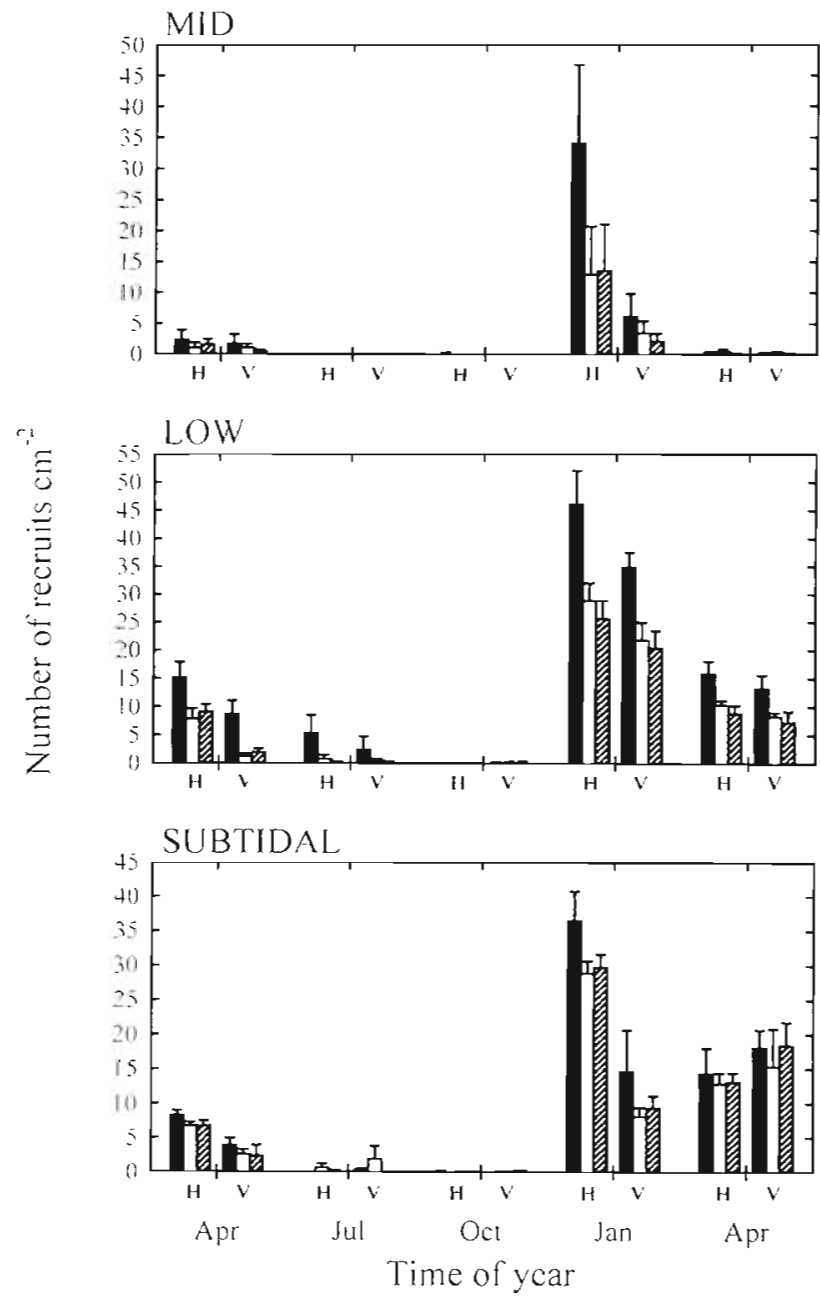

- exclusion lunce $\square$ openarea

Fig. 2. Hapalospongidion gelatinosum. Effects of herbivory (fence, fence control and open treatments), time and inclination (horizontal vs vertical surfaces) on recruit density (+SE) at 3 tidal heights; $\mathrm{n}=4$

\section{DISCUSSION}

\section{Effects of herbivory on recruitment}

Molluscan and echinoid herbivores occasionally reduced, but did not prevent, recruitment of algae. For Hapalospongidion gelatinosum and Ralfsia expansa recruit densities were reduced only during times of peak recruitment. During these periods, herbivore exclusions resulted in up to a 3 -fold increase in recruitment although, even in the presence of natural herbivore densities, large numbers of recruits survived (up to 17000 recruits $\mathrm{m}^{-2}$ ). It is unlikely that herbivory effectively limits the distribution of mature algal populations within the first month of recruitment. 
Table 3 Ralfsla expansa. Four-way ANOVA of recruit densities (mean number of individuals $\mathrm{cm}^{-2}$ ) by time, tidal height herbivory and inclination, followed by SNK multiple comparison tests for significant results. Abbreviations as in Table 2

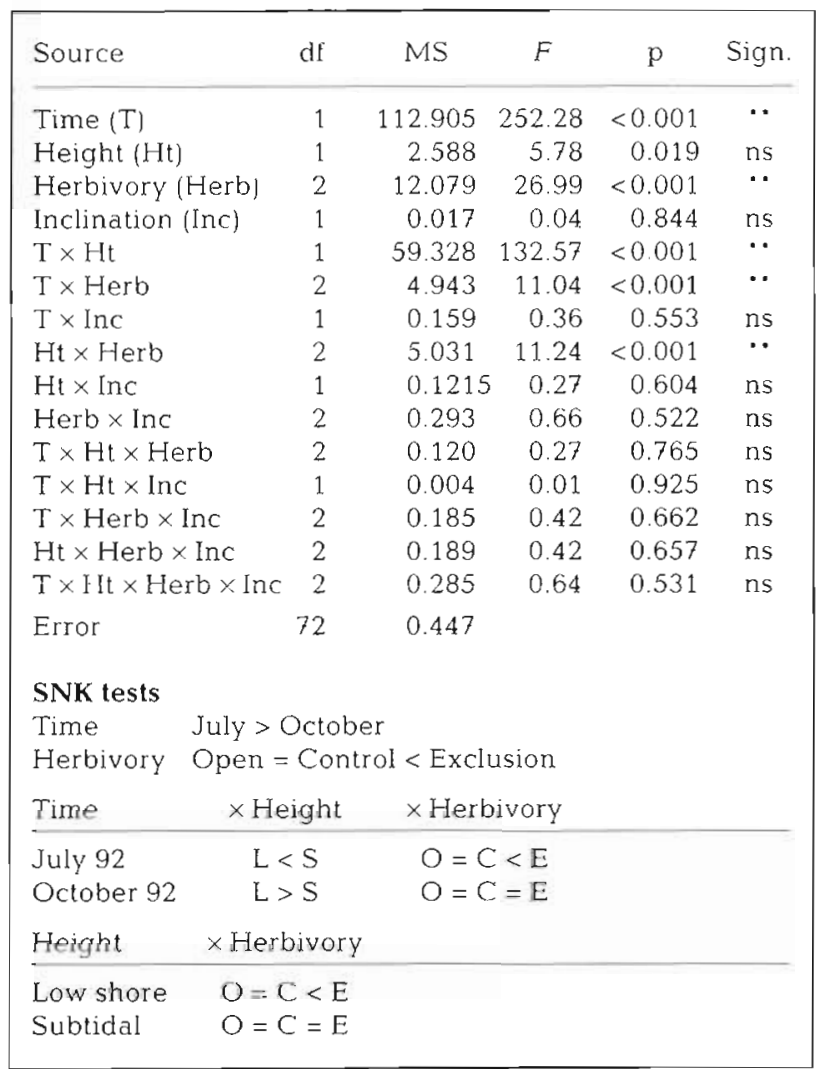

The effects of herbivory on algal recruitment have been shown to vary with physical parameters such as tidal height (Underwood 1985), variation in grazer densities and/or colonisation and growth rates of algae (Underwood \& Jernakoff 1981). In the present study, however, the density of encrusting algal recruits was reduced by herbivores at all tidal heights. Only for Ralfsia expansa in the subtidal did herbivore exclusions not result in significantly increased recruitment. This pattern is likely to be caused by increased densities of highly mobile herbivores (hermit crabs and fish) which, as plates had no roofs, were not effectively excluded from subtidal plates and which preferentially feed on $R$. expansa (Kaehler 1996).

The influence of herbivores also varied with time, although this was not directly related to seasonal changes in herbivore abundance (Kaehler 1996). In Hong Kong, intertidal herbivore densities are reduced each year with the advent of the hot season and are highest during winter (Kaehler \& Williams 1996). The temporal effect of herbivory on recruitment, however, varied between algal groups and was greatest during July for Ralfsia expansa and, conversely, in January for Hapalospongidion gelatinosum. Seasonal variation in
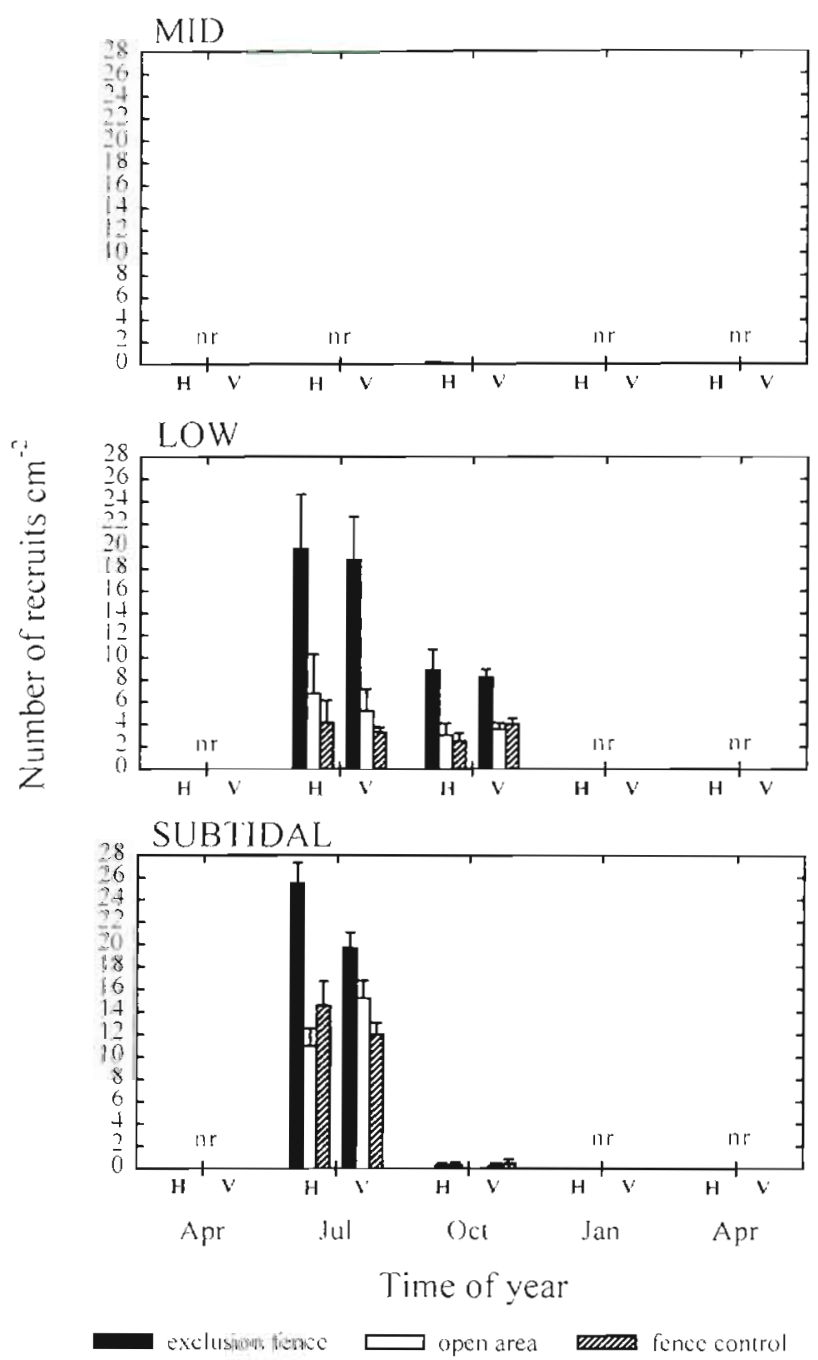

Fig. 3. Ralfsia expansa. Effects of herbivory (fence, fence control and open treatments), time and Inclination (horizontal vs vertical surfaces) on recruit density (+SE) at 3 tidal heights. $n r$ : no recruits observed at this time; $n=4$

molluscan and echinoid density does not, therefore, explain temporal changes in the effect of herbivores on algal recruitment. Of all recruiting species, only Peyssonnelia spp. and the structuraliy defended barnacles and spirorbids were continuously unaffected by herbivory (but see Williams 1994).

\section{Timing of recruitment}

All encrusting algae, erect macroalgae and sessile invertebrates exhibited temporal variation in recruitment, the majority recruiting during the cool season. Similar temporal variation in recruitment of other algal species is well documented (e.g. Deysher \& Norton 1982, Reed et al. 1988, Flavier \& Zingmark 1993. 
Table 4. Coralline crusts. Four-way ANOVA of recruit densities (mean number of individuals $\mathrm{cm}^{-2}$ ) by time, tidal height, herbivory and inclination, followed by SNK multiple comparison tests for significant results. Abbreviations as in Table 2

\begin{tabular}{|c|c|c|c|c|c|}
\hline \multicolumn{2}{|l|}{ Source } & MS & $F$ & $p$ & Sign \\
\hline \multicolumn{2}{|l|}{ Time (T) } & 41.527 & 140.99 & $<0.001$ & $\cdot \cdot$ \\
\hline \multicolumn{2}{|c|}{ Height $(\mathrm{Ht})$} & 123.847 & 420.48 & $<0.001$ & $\cdots$ \\
\hline \multicolumn{2}{|c|}{ Herbivory (Herb) } & 2.837 & 9.63 & $<0.001$ & . \\
\hline \multicolumn{2}{|c|}{ Inclination (Inc) } & 29.589 & 100.46 & $<0.001$ & $\because$ \\
\hline \multicolumn{2}{|c|}{$\mathrm{T} \times \mathrm{Ht}$} & 14.161 & 48.08 & $<0.001$ & $\because$ \\
\hline \multicolumn{2}{|l|}{$T \times$ Herb } & 0.541 & 1.84 & 0.070 & ns \\
\hline \multicolumn{2}{|l|}{$\mathrm{T} \times \operatorname{Inc}$} & 3.705 & 12.58 & $<0.001$ & $\cdots$ \\
\hline \multicolumn{2}{|l|}{$\mathrm{Ht} \times \mathrm{Herb}$} & 0.145 & 0.49 & 0.740 & ns \\
\hline \multicolumn{2}{|l|}{$\mathrm{Ht} \times \ln \mathrm{C}$} & 4.016 & 13.64 & $<0.001$ & $\cdots$ \\
\hline \multicolumn{2}{|c|}{ Herb $\times \operatorname{Inc}$} & 0.325 & 1.10 & 0.333 & ns \\
\hline \multicolumn{2}{|c|}{$\mathrm{I} \times \mathrm{Ht} \times$ Herb } & 0.424 & 1.44 & 0.122 & ns \\
\hline \multicolumn{2}{|c|}{$\mathrm{T} \times \mathrm{Ht} \times \operatorname{Inc}$} & 1.672 & 5.68 & $<0.001$ & $\cdot \cdot$ \\
\hline \multicolumn{2}{|c|}{ T $\times$ Herb $\times$ Inc } & 0.0789 & 0.27 & 0.976 & ns \\
\hline \multicolumn{2}{|c|}{$\mathrm{Ht} \times$ Herb $\times \operatorname{Inc}$} & 0.0959 & 0.33 & 0.861 & ns \\
\hline \multicolumn{2}{|c|}{$\mathrm{T} \times \mathrm{Ht} \times$ Herb $\times \ln \mathrm{c} 16$} & 0.174 & 0.59 & 0.889 & ns \\
\hline \multicolumn{2}{|c|}{ Error $\quad 270$} & 0.294 & & & \\
\hline \multicolumn{6}{|l|}{ SNK tests } \\
\hline $\begin{array}{l}\text { Time } \\
\text { Height } \\
\text { Herbivory } \\
\text { Inchnation }\end{array}$ & \multicolumn{5}{|c|}{$\begin{array}{l}\text { July = April } 92=\text { April } 93<\text { Octob } \\
\text { Mid shore }<\text { Low shore }<\text { Subtid } \\
\text { Open = Control }<\text { Exclusion } \\
\text { Vertical }<\text { Horizontal }\end{array}$} \\
\hline Time & $\times$ Height & \multicolumn{4}{|c|}{$x$ Inclination } \\
\hline April 92 & $M<L=S$ & \multicolumn{2}{|c|}{$\mathrm{V}<\mathrm{H}$} & & \\
\hline July 92 & $\mathrm{M}<\mathrm{L}<\mathrm{S}$ & \multicolumn{2}{|c|}{$\mathrm{V}=\mathrm{H}$} & & \\
\hline October 92 & $M<L>S$ & \multicolumn{2}{|c|}{$\mathrm{V}=\mathrm{H}$} & & \\
\hline January 93 & $\mathrm{M}<\mathrm{L}=\mathrm{S}$ & \multicolumn{2}{|c|}{$\mathrm{V}<\mathrm{H}$} & & \\
\hline April 93 & $\mathrm{M}=\mathrm{L}<\mathrm{S}$ & \multicolumn{2}{|c|}{$\mathrm{V}<\mathrm{H}$} & & \\
\hline Height & $x$ Inclination & & & & \\
\hline Mid shore & $\mathrm{V}=\mathrm{H}$ & & & & \\
\hline Low shore & $V=H$ & & & & \\
\hline Subtidal & $\mathrm{V}<\mathrm{H}$ & & & & \\
\hline Time $x$ Heis & ght $\times$ Incl & $\begin{array}{l}H>V \text { at } \\
\text { January } \\
\text { (except } \\
\text { otherwis }\end{array}$ & $\begin{array}{l}t \text { all hei } \\
\text { and at } \\
\text { July) in } \\
\text { se } \mathrm{H}=\end{array}$ & $\begin{array}{l}\text { ghts duri } \\
\text { all times } \\
\text { the subt }\end{array}$ & \\
\hline
\end{tabular}

Kendrick \& Walker 1994) and has frequently been related to the timing of reproduction (e.g. Deysher \& Norton 1982, Ang 1991). While the local environment may affect propagule release, dispersal, settlement and post-settlement mortality (reviewed by Santelices 1990), the temporal availability of fertile parent plants is in most cases a prerequisite for large scale recruitment (although colonisation through algal fragments is known; Fletcher \& Callow 1992).

Reproduction of Hapalospongidion gelatinosum and Ralfsia expansa is highly seasonal and coincides with periods of high recruitment (Kaehler 1996). In addition to reproductive periods, however, temporal abundance patterns of mature algal populations may also affect the availability of propagules. The abundance of the
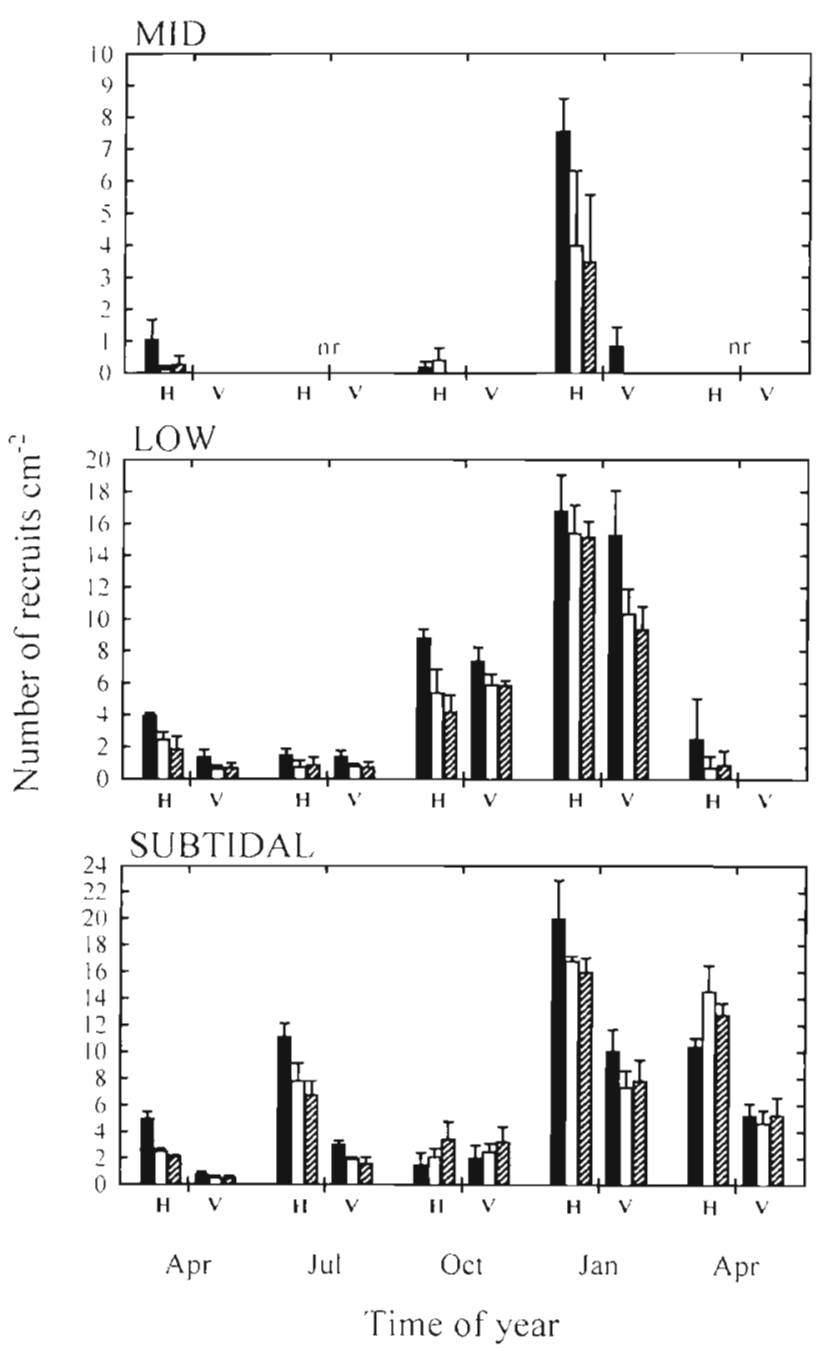

$\square$ exclusion fence $\square$ open area $\square$ men fence control

Fig. 4. Coralline crusts. Effects of herbivory (fence, fence control and open treatments), time and inclination (horizontal vs vertical surfaces) on recruit density (+SE) at 3 tidal heights. nr: no recruits observed at this time; $n=4$

mid shore $H$. gelatinosum is greatly reduced during the hot season (Kaehler \& Williams 1996) and the availability of its propagules is, therefore, likely to be low at this time. In contrast, mature populations of $R$ expansa and the coralline crusts are found lower on the shore and persist in the subtidal throughout the year (Kaehler \& Williams 1996), which may account for their ability to recruit in greater numbers during the hot season (see also Underwood \& Denley 1984).

\section{Vertical distribution of recruits}

All 3 abundant encrusting algal groups recruited in greatest densities on the low shore and/or in the sub- 
tidal. Recruitment was reduced on the mid shore and there was no recruitment on the high shore. As most algal spores are non-motile (Fletcher \& Callow 1992), environmental conditions are thought to determine their deposition and potential settlement (Santelices 1990). Increased recruitment to lower tidal heights may, therefore, be a function of prolonged submergence (Hruby \& Norton 1979, Underwood \& Denley 1984, Underwood 1985). Additionally, the close proximity of parent plants (see also Williamson \& Creese 1996) may be important, especially for the encrusting algal form group, as their low point of spore release and the reduced water velocities of the boundary layer may increase the probability of settling close to the propagule source (Santelices 1990).

An alternative explanation for increased recruitment towards lower shore levels is an increase in post-settlement mortality at higher shore levels. In Hong Kong, during the hot season (July and October), recruitment was restricted to the low shore and the subtidal, while during the cool season (January and April), species recruited at higher tidal levels (the mid shore), suggesting that the upper limits of recruits are at least partially determined by the physical environment (see also Flavier \& Zingmark 1993). Hapalospongidion gelatinosum and the coralline crusts which recruit dur-

Table 5. Mean recruit densities $\mathrm{cm}^{-2}$ (SE in parentheses) of rare or patchily distributed organisms at different tidal heights, herbivore treatments and inclinations. Abbreviations as in Table 2

\begin{tabular}{|c|c|c|c|}
\hline & Tidal height & Herbivory & Inclination \\
\hline $\begin{array}{l}\text { Crustose algae } \\
\text { Peyssonnelia spp. }\end{array}$ & 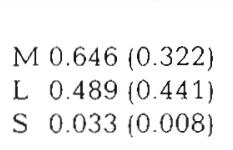 & $\begin{array}{l}O 0.576(0.449) \\
C 0.334(0.284) \\
\text { E } 0.256(0.130)\end{array}$ & $\begin{array}{l}\text { H } 0.628(0.355) \\
\text { V } 0.151(0.077)\end{array}$ \\
\hline $\begin{array}{l}\text { Erect algae } \\
\text { Gelidium spp. }\end{array}$ & $\begin{array}{lc}M & <0.001 \\
L & 0.001(0.001) \\
S & 0.020(0.005)\end{array}$ & $\begin{array}{l}O 0.005(0.003) \\
C 0.001(0.001) \\
\text { E } 0.016(0.005)\end{array}$ & $\begin{array}{l}\text { H } 0.009(0.002) \\
\text { V } 0.006(0.003)\end{array}$ \\
\hline Porphyra spp. & $\begin{array}{ll}\text { M } & 0.386(0.146) \\
\mathrm{L} & \mathrm{nr} \\
\mathrm{S} & \mathrm{nr}\end{array}$ & $\begin{array}{l}O 0.108(0.069) \\
C 0.094(0.068) \\
\text { E } 0.183(0.075)\end{array}$ & $\begin{array}{l}\text { H } 0.066(0.047) \\
\text { V } 0.193(0.087)\end{array}$ \\
\hline Brown spores & $\begin{array}{lc}M & 0.092(0.086) \\
L & n r \\
S & 0.100(0.051)\end{array}$ & $\begin{array}{l}O 0.020(0.011) \\
C \quad<0.001 \\
\text { E } 0.172(0.098)\end{array}$ & $\begin{array}{l}\text { H } 0.083(0.058) \\
\text { V } 0.045(0.003)\end{array}$ \\
\hline Green spores & 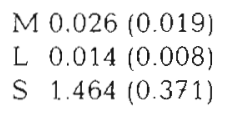 & $\begin{array}{l}O 0.308(0.144) \\
C 0.235(0.153) \\
\text { E } 0.961(0.321)\end{array}$ & $\begin{array}{l}\text { H } 0.468(0.193) \\
\text { V } 0.535(0.170)\end{array}$ \\
\hline $\begin{array}{l}\text { Invertebrates } \\
\text { Barnacles }\end{array}$ & 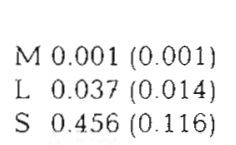 & $\begin{array}{l}O \quad 0.225(0.092) \\
C 0.121(0.042) \\
\text { E } 0.148(0.066)\end{array}$ & $\begin{array}{l}\text { H } 0.134(0.038) \\
\text { V } 0.195(0.070)\end{array}$ \\
\hline Spirorbids & $\begin{array}{lc}M & n r \\
L & 0.535(0.125) \\
S & 1.048(0.183)\end{array}$ & $\begin{array}{l}O 0.476(0.117) \\
C 0.558(0.131) \\
\text { E } 0.550(0.151)\end{array}$ & $\begin{array}{l}\text { H } 0.202(0.040) \\
\text { V } 0.853(0.145)\end{array}$ \\
\hline
\end{tabular}

ing periods of reduced physical stress extend higher on the shore than Ralfsia expansa which recruits only during the hot season. As susceptibility to physical stress is greatest in juvenile stages (Hruby \& Norton 1979, Norton 1986, Davison et al. 1993), the potential upper limit of mature encrusting algal populations is probably determined at a very early stage of development and strongly affected by the relative timing of recruitment.

In contrast, the recruitment of other macroalgal species did not always increase down shore. Both Peyssonnelia spp. and Porphyra sp. were most abundant on the mid shore and unidentified brown spores exhibited a bimodal distribution with peaks on the mid shore and subtidal. Neither physical gradients nor active site selection could account for these patterns.

\section{Distribution of recruits with substratum inclination}

Both Hapalospongidion gelatinosum and the coralline crusts were more abundant on horizontal as opposed to vertical surfaces at times (January and April) and/or tidal heights (low shore and subtidal) of reduced physical stress. In contrast, during the hot season and at higher shore levels, the abundance of recruits of all 3 encrusting algae did not differ between horizontal and vertical surfaces. Recruitment is, therefore, generally greater on horizontal surfaces, except where physical conditions preclude this pattern from occurring, although the reasons for this pattern are unknown.

Hydrographic conditions may partially account for increased settlement on horizontal surfaces, where the microtopography of the roughened settlement plates may enhance propagule deposition (see Norton \& Fetter 1981). Furthermore, overall greater wave impact and turbulence may decrease settlement and increase dislodgement on vertical surfaces. During the hot season and at higher shore levels, however, increased mortality on horizontal surfaces may alter this pattern. Previous studies in the vicinity have shown that horizontal surfaces may reach temperatures of $50^{\circ} \mathrm{C}$ (Williams 1994) and are hotter (3 to $7^{\circ} \mathrm{C}$ ) than vertical surfaces (Williams \& Morritt 1995). This may account for the greater recruitment on horizontal surfaces primarily at low tidal heights and/or during the cool season. Variation in the abundance of 
macroalgae with inclination have been documented (Konno 1985, Sebens 1986, Dethier et al. 1991, Kaehler \& Williams 1996) and differences in grazing pressure have been suggested to partially account for these patterns. In the present study, however, recruit densities were greater on horizontal surfaces irrespective of herbivore presence, suggesting that molluscan and echinoid herbivores were not responsible for varying recruitment with inclination. In contrast to the algae, all invertebrates recruited in higher densities on vertical as opposed to horizontal surfaces. The mechanisms generating this pattern are unknown, but the distribution of sessile invertebrate recruits has previously been linked to physical, biotic and/or chemical factors (reviewed by Rodríguez et al. 1993).

\section{Implications for the distribution of encrusting algae}

Despite the ability of molluscan and echinoid grazers to reduce the number of encrusting algal recruits, natural grazer densities were not sufficient to directly restrict the distribution of algae during the first month of colonisation. In contrast, the timing of recruitment and the prevailing environmental conditions strongly affected the abundance and distribution of encrusting algae even during the first month of colonisation. Recruit densities generally decreased towards areas of increased physical stress (high shore), and during the hot season recruitment was restricted exclusively to the low shore and subtidal. Species that only recruited during the hot season (Ralfsia expansa) were thus not capable of colonising above the low shore, whilst groups that additionally recruited during the cool season (Hapalospongidion gelatinosum and the coralline crusts) could colonise higher shore levels (mid shore).

Recruitment never occurred above the natural recorded vertical extent of mature populations (Kaehler \& Williams 1996), suggesting that the upper limits of encrusting algal populations are set during the early stages of colonisation (see also Kaehler 1996). In contrast, the lower distribution of adult populations was not always directly related to recruitment patterns. For example, Hapalospongidion gelatinosum, which naturally occurs primarily on the mid shore (Kaehler \& Williams 1996), recruited far below the vertical extent of adult populations during all study periods. H. gelatinosum, however, recruits primarily during the cooler parts of the year, when space is not freely available at lower tidal heights (Kaehler \& Williams 1996) and previous space occupants will compete with or directly affect newly arriving recruits (Fletcher 1975, Breitburg 1984, Benedetti-Cecchi \& Cinelli 1992). Realised recruitment at lower shore heights is therefore likely to be much reduced when compared to recruitment onto new settle- ment plates. Even where recruitment does naturally occur to the low shore, however, $H$. gelatinosum is readily overgrown by the competitively superior Ralfsia expansa (Kaehler 1996). $R$. expansa recruits only during the hotter parts of the year, when space is more freely available on the low shore (Kaehler \& Williams 1996). This suggests that encrusting algae may exhibit dissimilar life-history strategies along the tidal gradient. Species that recruit mainly during the hot season $(R$. expansa) may be adapted to colonise the low shore at a time when space is available and may persist there by means of their superior overgrowth capabilities. In contrast, species that recruit primarily during the physically less stressful cool season have to utilise space at higher shore levels (e.g. mid shore) where bare substratum is available throughout the year and competitive interactions are of reduced importance in determining initial colonisation and subsequent development. The penalty for recruitment at this tidal level is increased physical stress, which during the hot season kills off the majority of adult algae.

Acknowledgements. We gratefully acknowledge P. Collinson, K. Harper and J. Hall-Spencer for their help with the initial construction of the experiment and Dr Mak Yiu Ming and especially Ms Kelly Lau Laj Yip for help with the figures. This work was carried out in partial fulfilment of the requirements for a Ph.D. by S.K. and was supported by a Unuversity of Hong Kong studentship.

\section{LITERATURE CITED}

Adey WH, Vassar JM (1975) Colonisation, succession and growth rates of tropical crustose coralline algae (Rhodophyta, Cryptonemiales). Phycologia 14:55-69

Ang Jr PO (1991) Natural dynamics of a Fucus distichus (Phaeophyceae, Fucales) population: reproduction and recruitment. Mar Ecol Prog Ser 78:71-85

Benedetti-Cecchi L, Cinelli F (1992) Effects of canopy cover, herbivores and substratum type on patterns of Cystoseira spp. settlement and recruitment in littoral rockpools. Mar Ecol Prog Ser 90:183-191

Benedetti-Cecchi L, Cinelli F (1993) Early patterns of algal succession in a midlittoral community of the Mediterranean sea: a multifactorial experiment. J Exp Mar Biol Ecol 169:15-31

Breitburg DL (1984) Residual effects of grazing: inhibition of competitor recruitment by encrusting coralline algae. Ecology 65:1136-1143

Brosnan DM (1992) Ecology of tropical rocky shores: plantanimal interactions in tropical and temperate latitudes. In: John DM, Hawkins SJ, Price JH (eds) Plant-animal interactions in the marine benthos. Spec Vol 46. Systematics Association, Clarendon Press, Oxford, p 101-131

Chamberlain AHL (1976) Algal settlement and secretion of adhesive materials. In: Sharpley JM, Kaplam AM (eds) Proc Third Int Biodegrad Symp. Applied Science Publishers, London, p 417-432

Connell JH (1985) The consequences of variation in initial settlement vs. post-settlement mortality in rocky intertidal communities. J Exp Mar Biol Ecol 93:11-45 
Davison IR, Johnson L.E, Brawley SH (1993) Sublethal stress in the intertidal zone: tidal emersion inhubits photosynthesis and retards development in embryos of the brown alga Pelvetia fastigiata. Oecologia 96:483-492

Dayton PK (1985) Ecology of kelp communities. Ann Rev Ecol Syst 16:215-245

Dethier MN, Paull KM, Woodbury MM (1991) Distribution and thickness patterns in subtidal encrusting algae from Washington. Bot Mar 34:201-210

Deysher L, Norton TA (1982) Dispersal and colonisation in Sargassum muticum (Yendo) Fensholt. J Exp Mar Biol Ecol 56:179-195

Doherty P, Williams DMcB (1988) The replenishment of coral reef fish populations. Oceanogr Mar Biol Annu Rev 26: $487-551$

Flavier AB, Zingmark RG (1993) Macroalgal recruitment in a high marsh creek of North Inlet Estuary, South Carolina. J Phycol 29:2-8

Fletcher RL (1975) Heteroantagonism observed in mixed algal cultures. Nature 253:534-535

Fletcher RL, Callow ME (1992) The settlement, attachment and establishment of marine algal spores. Br Phycol J 27 . $303-329$

Foster MS (1975) Regulation of algal community development in a Macrocystis pyrifera forest. Mar Biol 32:331-342

Geller JB (1991) Gastropod grazers and algal colonization on a rocky shore in northern California: the importance of the body size of grazers. J Exp Mar Biol Ecol 150:1-1.7

Hixon MA, Brostoff WN (1985) Substrate characteristics, fish grazing, and epibenthic reef assemblages off Hawaii. Bull Mar Sci 37:200-213

Hoffmann AJ (1987) The arrival of seaweed propagules at the shore: a review. Bot Mar 30:151-165

Hoffmann AJ, Ugarte R (1985) The arrival of propagules of marine macroalgae in the intertidal zone. J Exp Mar Biol Ecol 92:83-95

Hruby T, Norton TA (1979) Algal colonization on rocky shores in the Firth of Clyde. J Ecol 67:65-77

Hurlbert SH (1984) Pseudoreplication and the design of ecological field experiments. Ecol Monogr 54:187-21.1

Jernakoff P (1983) Factors affecting the recruitment of algae in a mid shore region dominated by barnacles. J Exp Mar Biol Ecol 66:17-31

Kaehler S (1994) The non-coralline epilithic encrustung algae of Hong Kong. Asian Mar Biol 11:49-57

Kaehler S (1996) Causes and consequences of the spatial and temporal distribution of encrusting algae on tropical rocky shores. PhD thesis, University of Hong Kong

Kaehler S, Williams GA (1996) Distribution of algae on tropical rocky shores: spatial and temporal patterns of non-coralline encrusting algae in Hong Kong. Mar Biol 125:177-187

Kendrick GA (1994) Effects of propagule settlement density and adult canopy on survival of recruits of Sargassum spp. (Sargassaceae: Phaeophyta). Mar Ecol Prog Ser 103: $129-140$

Kendrick GA, Walker DI (1994) Role of recruitment in structuring beds of Sargassum spp. (Phaeophyta) at Rottnest Island, Western Australia. J Phycol 30:200-208

Keough MJ, Downes BJ (1982) Recruitment of marine invertebrates: the role of active larval choices and early mortality. Oecologia 54:348-352

Konno T (1985) Effects of inclination of a rocky surface on the distribution of sublittoral sessile organisms. J Tokyo Unıv Fish 72:99-109

Menge BA, Farrell T (1989) Community structure and interaction webs in shallow marine hard-bottom communities: tests of an environmental stress model. Adv Ecol Res 19:189-262
Norton TA (1985) The zonation of seaweeds on rocky shores In: Moore PG, Seed $R$ (eds) The ecology of rocky coasts Hodder and Stoughton, London, p 7-21

Norton TA (1986) The ecology of macroalgae in the Firth of Clyde. Proc R Soc Edinburgh 90B:255-269

Norton TA, Fetter R (1981) The settlement of Sargassum muticum propagules in stationary and flowing water. J Mar Biol Ass UK 61:929-940

Reed DC, Laur DR, Ebeling AW (1988) Variation in algal dispersal and recruitment: the importance of episodic events. Ecol Monogr 58:321-335

Rodriguez SR, Ojeda FP, Inestrosa NC (1993) Settlement of benthic marine invertebrates. Mar Ecol Prog Ser 97:193-207

Santelices B (1990) Patterns of reproduction, dispersal and recruitment in seaweeds. Oceanogr Mar Biol Ann Rev 28: $177-276$

Santelices B, Ojeda FP (1984) Recruitment, growth and survival of Lessonia nigrescens (Phaeophyta) at various tidal levels in exposed habitats of central Chile. Mar Ecol Prog Ser 19:73-82

Sebens KP (1986) Spatial relationships among encrusting marine organisms in the New England subtidal zone. Ecol Monogr 56:73-96

Underwood AJ (1980) The effects of grazing by gastropods and physical factors on the upper limits of the distribution of intertidal macroalgae. Oecologia 46:201-213

Underwood AJ (1985) Physical factors and biological interac tions: the necessity and nature of ecological experiments In: Moore PG, Seed R (eds) The ecology of rocky coasts. Hodder and Stoughton, London, p 372-390

Underwood AJ (1991) The logic of ecological experiments: a case history from studies of the distribution of macroalgae on rocky intertidal shores. J Mar Biol Ass UK 71:841-866

Underwood AJ, Denley EJ (1984) Paradigms, explanations, and the generalisations in models for the structure of intertidal communities on rocky shores. In: Strong DR, Simberloff $\mathrm{D}$, A bele LG, Thistle AB (eds) Ecological communities: conceptual issues and the evidence. Princeton University Press, Princeton, p 151-180

Underwood AJ, Fairweather PG (1989) Supply-side ecology and benthic marine assemblages. TREE $4: 16-20$

Underwood AJ, Jernakoff P (1981) Effects of interactions between algae and grazing gastropods on the structure of a low-shore intertidal algal community. Oecologia 48 $221-233$

Williams GA (1993a) Seasona) variation in algal species richness and abundance in the presence of molluscan herbivores on a tropical rocky shore. J Exp Mar Biol Ecol 167:261-275

Williams GA (1993b) The relationship between herbivorous molluscs and algae on moderately exposed Hong Kong shores. In: Morton B (ed) The marine biology of the South China Sea. Proceedings of the First International Conference on the Marine Biology of Hong Kong and the South China Sea. Hong Kong University Press, Hong Kong, p $459-469$

Williams GA (1994) The relationship between shade and molluscan grazing in structuring communities on a moderately-exposed tropical rocky shore. J Exp Mar Biol Ecol 178:79-95

Williams GA, Morritt D (1995) Habitat partitioning and thermal tolerance in a tropical limpet, Cellana grata. Mar Ecol Prog Ser 124:89-103

Williamson JE, Creese RG (1996) Colonisation and persistence of patches of the crustose brown alga Pseudolithoderma sp. J Exp Mar Biol Ecol 203:191-208

Zar JH (1984) Biostatistical analysis. Prentice Hall, Englewood Cliffs, NJ 